Katarzyna Węsierska, Ph.D.

Polish Language Insitute

University of Silesia in Katowice

\title{
THE (PRE)SCHOOL SITUATION OF CHILDREN WITH COMMUNICATION DISORDERS
}

\author{
There is a direct relation between quality of \\ communication and quality of life.
}

J. Stewart, Bridges Not Walls, 2007, p. 27

\section{Introduction}

Interpersonal communication skills are regarded as extremely influential on various aspects of human functioning. The process of communication especially influences building one's identity as well as shaping the image of oneself. Interpersonal interactions realized through communication lead to establishment and maintenance of relations with others (Alberts, Nakayama, Martin, 2007). According to the dictionary definition, communication is a process of "(...) expressing thoughts, providing information" (Sobol [ed.], 1999, p. 332). Taking this into consideration, it is hard to imagine fully functioning citizens within society with either partial or no ability to communicate with their surroundings. The authors of the textbook about interpersonal communication, S.P. Morreale, B.H. Spitzberg and J.K. Barge especially emphasise that the way in which people communicate with each other substantially influences their ability to build strong and healthy societies (2007). Therefore the occurrence of any communication disorders impairs human beings and considerably influences their functioning in society.

In this context, the Polish statistics derived from the field of speech-language pathology are alarming. Both national and local research show a constant increase in speech disorders among preschool and early primary school children over the last years (Jastrzębowska, 2003; Kania, 2001; Michalak-Widera, 2004; Trzaskalik, 1998; Węsierska, 2009). The speech screening research conducted by the author of this article among preschool children in Katowice betweem the years 2003 and 2006 showed consistently maintained speech disorders in children at the 
level of approximately 44\% (Węsierska, 2009). Over the years, the educational environment has been paying attention to the relation between communication disorders and emotional or behavioural problems. It is emphasised that the consequences of communication disorders can be reflected in children's difficulties in school performance (Spionek, 1965). Children with speech disorders are regarded as a group with an increased risk of learning disabilities and even emotional and mental disturbances (Wintgens, 2002). In such cases there is a possibility that the following phenomena may occur: negative school attitude, decreased learning motivation, deterioration of cognitive skills. All of these phenomena can also lead to school failures and lack of social adjustment in the future (Cantwell, Baker, 1985). Moreover, children with speech disorders are often more poorly perceived by their peers. Research conducted in the Silesia region showed that $81 \%$ of juniors from $1^{\text {st }}$ to $3^{\text {rd }}$ grade and $42 \%$ of juniors 4 th to 6 th grade had serious problems with the understanding of peers' statements with speech disorders (Matyja, Cudak, 2009). Polish researcher E. Stecko signals the negative influence of communication difficulties on a child's personality development, self-esteem as well as quality of interpersonal relationships (2001). M.L. Rice Claims that as early as Kindergarten one can hear such phrases as: "do not talk to him - he is strange" (1993, p. 139), directed at children with communication disorders. Also, Rice's studies showed that children among whom language and speech development is disrupted have worse relations with peers. What is more, according to this researcher, there is a correlation between disruptions of speech development and the interpersonal social sphere. In the case of developmental problems in communication a specific type of vicious circle can be considered, because socialization processes constitute the main source of language development, and correct language development is an essential tool in order to socialize. American researchers M.L. Rice, M.A. Sell and P.A. Hadley showed that speech disorders even during preschool development negatively affect children's relationships with peers (1990). During play with peers, children with normal speech development were more preferred partners, while their friends who featured communication disorders were considerably more neglected and ignored. E.M. Skorek highlighted another important factor, namely that as a result of communication difficulties, pupils with diagnosed speech disorders have limited peer relations both in and outside the school. Moreover, those children in the sociometrical group structure are often in an isolation and rejection position (2000). Furthermore, studies conducted among teachers indicated that a substantial group shows unfavourable attitudes towards pupils who display difficulties in communication. A lot of teachers, both in Polish as well as British studies, are characterised as having a stereotypical image of children with speech development disorders (Ebert, Prelock, 1994; Grzybowska, Łapińska, Michalska, 1991; Lass et al., 1992; Lees, 2000; Kasprzyk, Stasiczek, Węsierska, 2005). Studies showed that teachers regard referring a child to a specialist as a basic method of support for pupils with speech disorders. 
The aim of this study was to analyze the opinions of teachers/pedagogues regarding the educational situation of children with speech disorders. The following questions were asked:

- Where does a teacher look for help for children with communication disorders?

- What are the main speech disorders among preschool children and juniors?

- What are the typical behaviours of children/juniors with speech disorders and the most popular peers' reactions to these communication problems?

- What are the possible forms of support for children with speech disorders that are offered by teachers?

- What is the level of teachers' interest in improving their professional careers in the field of speech-language pathology?

\section{Method of Research Conduct}

The research was conducted in 2011 - from January until May - among teachers and pedagogues from Śląsk, Małopolska and Łódź Provinces. The method of diagnostic polls was used in the research. The surveys were filled out by 483 respondents. Each survey consisted of 7 semi open-ended questions, where the teachers had the opportunity to add their own opinions. The demographic data which was obtained consisted of gender, type of institution in which each respondent was working and the specialization as well as seniority in the teaching profession.

\section{Participants}

Teachers and pedagogues from various kinds of schools as well as kindergartens took part in the study. 439 participants answered the question regarding gender while 44 did not provide such information. Of these 439,411 were female and the remaining 28 were male. Respondents represented various kinds of educational institutions. The most numerous group consisted of primary school teachers (284). The second most numerous group consisted of lower secondary schools (90 persons) and kindergarten (72 persons) teachers. Furthermore, secondary school/technical secondary school teachers ( 37 persons) constituted the smallest group. The answer - "other type of institution" - was indicated by 20 participants. This category embraced the educational institutions such as: special vocational schools, post-secondary schools, job-training schools, basic vocational schools and tertiary education. Information regarding seniority was indicated by 471 respondents (there was more than one option to choose). Among all participants, 
a group of long-serving teachers dominated, with more than twenty-years of work experience. This category was chosen by 162 respondents. The next two groups 86 participants in each - consisted of individuals with 11 to 20 and 5 to 10 years of work experience. Pedagogues with relatively short seniority, below 5 years, constituted the smallest group which counted 54 participants. There were 31 individuals who did not provide information regarding seniority.

\section{Analysis of the Results}

The first issue which was assessed concerned the choice of specialist to whom teachers referred pupils with speech disabilities (Figure 1).

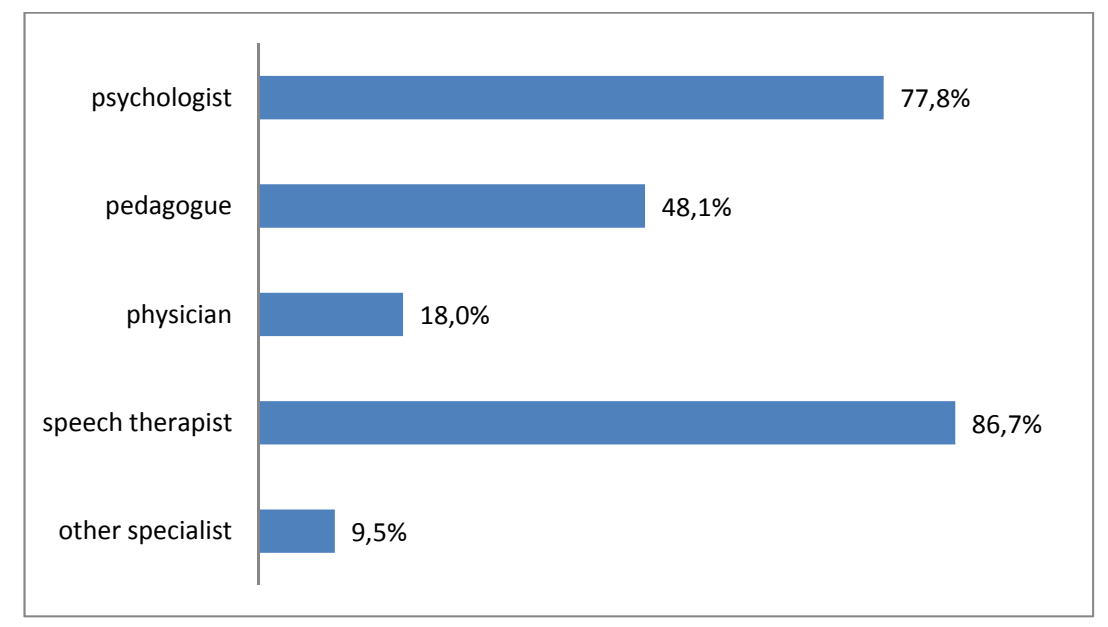

Figure 1. Specialists recommended by the teachers in the case of occurrence of communications disorders among children; $\mathrm{N}=483$

Respondents could choose more than one answer.

Source: Own work

The answers provided to this question indicated that the speech-therapist's profession is adequately assessed by pedagogues and teachers. Also, the tendency towards professionalization and institutionalization of the speech therapist's profession was clearly confirmed by this research which was also observed in various studies in this area over the past years. A speech therapist is more and more often regarded as a specialist whose profession consists of the treatment of various types of communication disorders (Dramska 2001a, 2001b; Tarkowski, 2005). Moreover, most of the respondents indicated that they would refer a pupil to the speech therapist if they show communication disorders. It Interestingly, 
the pschologist profession... was indicated on the second position in this hierarchy. In relation, it can be assumed that teachers associate speech disorders with behavioural or group functioning problems. Probably due to this fact, the next indicated specialist to whom teachers would refer a pupil was a school pedagogue. Presumably the choice of pedagogue and psychologist is connected with the fact that teachers and pupils have the most frequent contact with these specialists, if a speech therapist is not employed in their institution. This situation usually occurs in lower secondary and secondary schools but also frequently even in primary schools. The explanation of this can be the fact that speech therapists are mostly employed in kindergartens. While filling out the survey teachers chose a physician considerably less often as a specialist to whom they would refer a child with speech disorders. This could be caused by limitations in contact between physicians and teachers due to the closing down of the physicians' offices in schools and kindergartens. Among other specialists, the respondents indicated medical professions including laryngologist, neurologist, audiologist, phoniatrist, stomatologist, orthodontist, physiotherapist and psychiatrist. One of the respondents indicated an actor, whereas another respondent indicated a neuro-speech therapist. Also in one of the surveys a counselling clinic was indicated which is an institution where speech therapists, psychologists and pedagogues are employed.

The next issue which was analysed in this study refers to the factors which, according to teachers, should influence the decision to provide a pupil/child with specialist help (Figure 2).

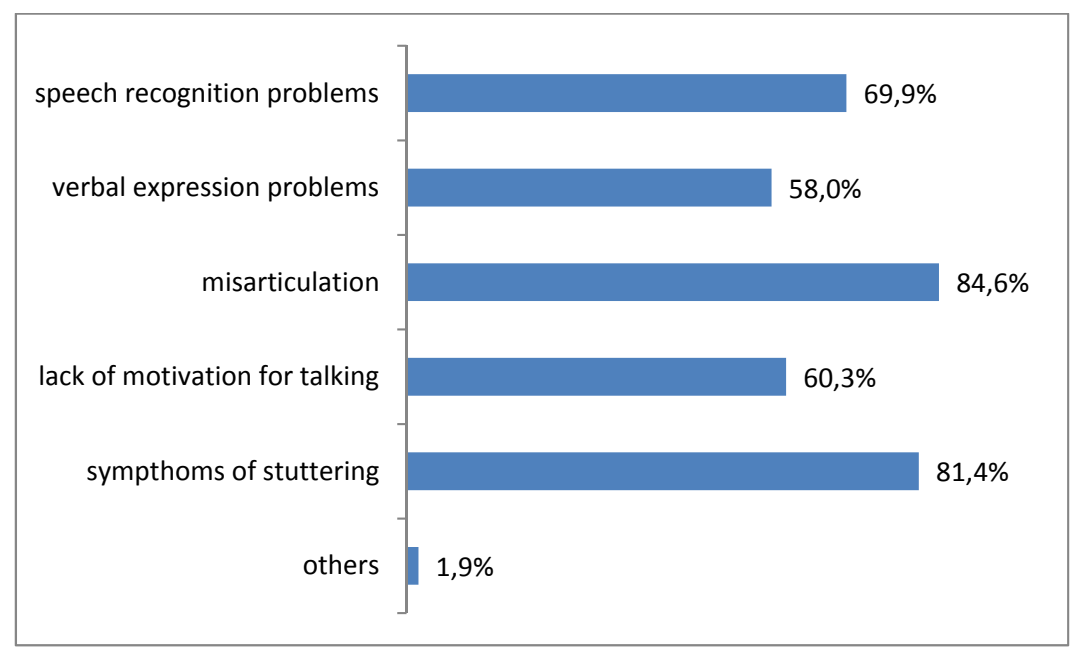

Figure 2. Factors which according to teachers decide about providing pupils with specialist help of speech therapists; $\mathrm{N}=483$

Respondents could choose more than one answer.

Source: Own work 
According to the opinion of teachers, misarticulation is the most common factor which could alarm a teacher that pupils need a specialist consultation. More than $84 \%$ of the respondents indicated such an answer. This confirms a tendency which has appeared in previous studies, namely that teachers concentrate on speech disorders (Węsierska, 2009). Stuttering (speech disfluencies) has been indicated by pedagogues as the second most alarming factor. It can be assumed that difficulties in social interactions with which stuttering individuals have to contend, are noticed by the majority of pedagogues. Further symptoms of communication disorders, which were recognized by teachers as requiring specialist intervention, occurred in the following order: speech recognition problems (e.g. hearing-impairment, central hearing disorders), verbal expression problems (e.g. deleted speech development) as well as lack of motivation for talking. It seems to be a common notion that logopedic problems consist mainly of articulation impediments. That is why the influence of other kinds of communication disorders, especially on social and emotional functioning, should be well-publicized among the milieu of pedagogues.

In this study, teachers also indicated the speech impediments they have the most frequent contact with during their professional experience (Figure 3).

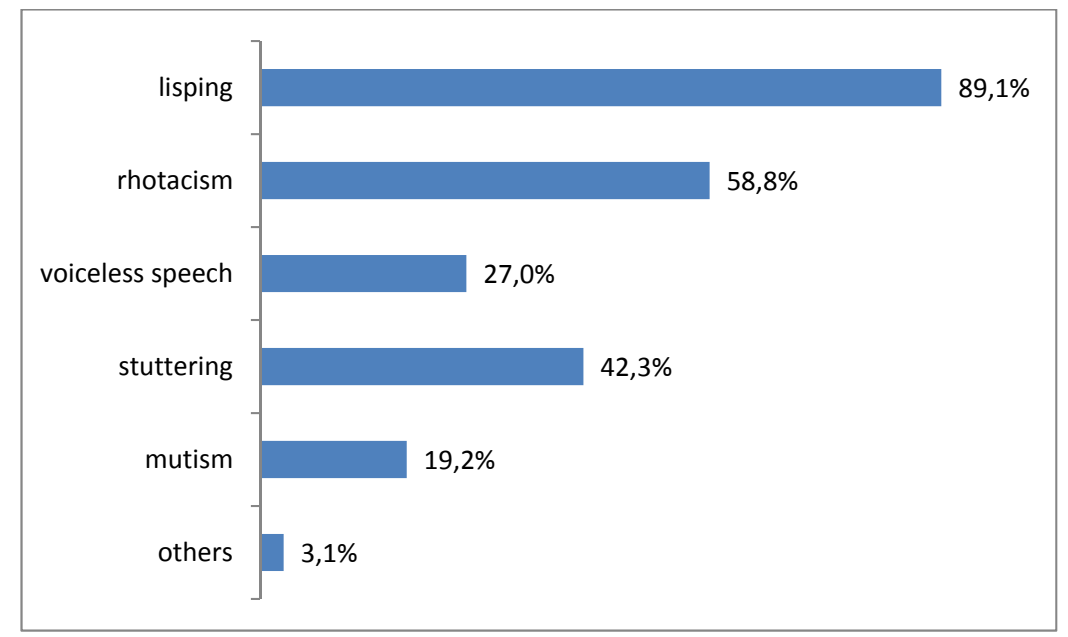

Figure 3. The most common speech impediments among children indicated by teachers; $N=483$ Respondents could choose more than one answer.

Source: Own work

According to the respondents, speech impediments appeared to be the ones regarded as the most alarming and requiring specialist consultation. These results were similar to those concerning symptoms of speech disorders. Lisping (improper pronunciation of dental sounds) and rhotacism (improper pronunciation of the " $r$ " sound) were placed highest on this list. This can be explained by the fact that 
speech impediments are one of the most common forms of all speech disorders during early stages of development (Van Riper, Erickson, 1996). Stuttering was the next disorder indicated by teachers. A high frequency ( $27 \%$ of answers) occurred for voiceless speech which is the devoicing pronunciation of sounds which have their voiced equivalents (e.g. instead of the word buda the pupil pronounces puta). Frequent indication of voiceless speech, often regarded as dyslalia (speech impediments), confirms the teachers' focus on pronunciation problems. Other speech disorders pointed out by teachers mainly concern delayed speech development, poor speech clarity, "talking with a mouth almost closed despite a fully functioning vocal apparatus", logophobia, kappasism (the change of a sound from " $\mathrm{k}$ " to " $\mathrm{t}$ " or the lack of pronunciation of this sound), gammasism (the change of a sound from "g" to " $\mathrm{d}$ " or the lack of pronunciation of this sound), lallation (mispronunciation of the sound "l", substituting it with an easier sound to pronounce or lack of pronunciation of this sound), the use of a diminutive form of words, careless, unclear speech, respiratory problems, speech impediments coupled with other defects, lack of vocalizing of first sounds in words. The responses quoted above confirm a strong concentration of pedagogues on the quality of made statements, especially regarding pronunciation. On the other hand the decreased interest of the teachers in realising pragmatic communication with their pupils is quite disturbing.

The subsequent matter which was subjected for evaluation by the teachers concerned the most frequent behaviours and reactions of peers (kindergarten group or class) in relation to children/pupils with speech disorders (Figure 4).

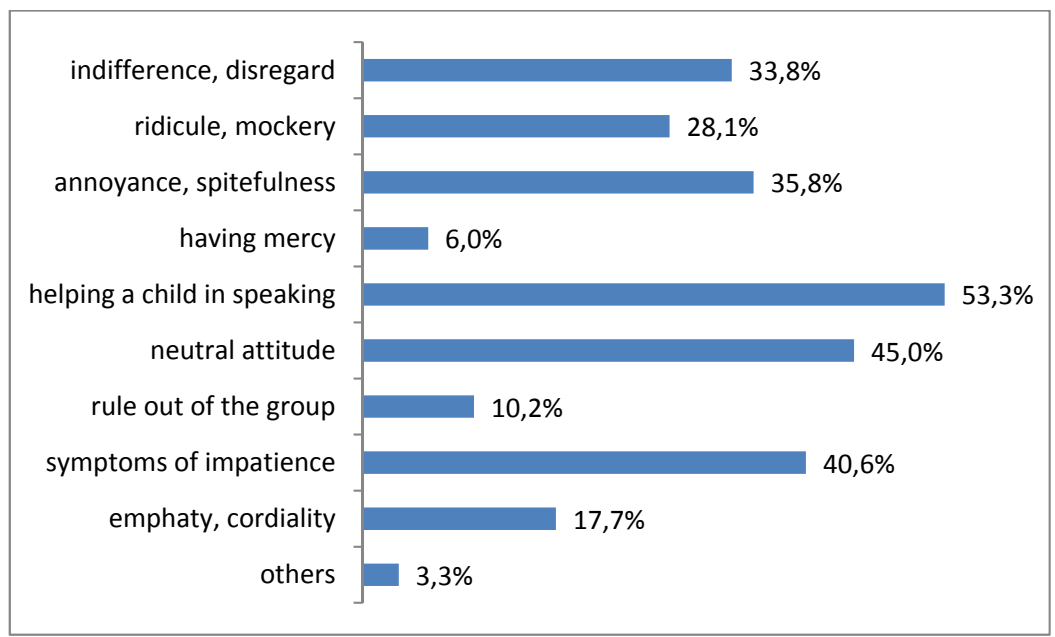

Figure 4. Typical reactions of peers in relation to children with speech disorders; $N=483$ Respondents could choose more than one answer.

Source: Own work 


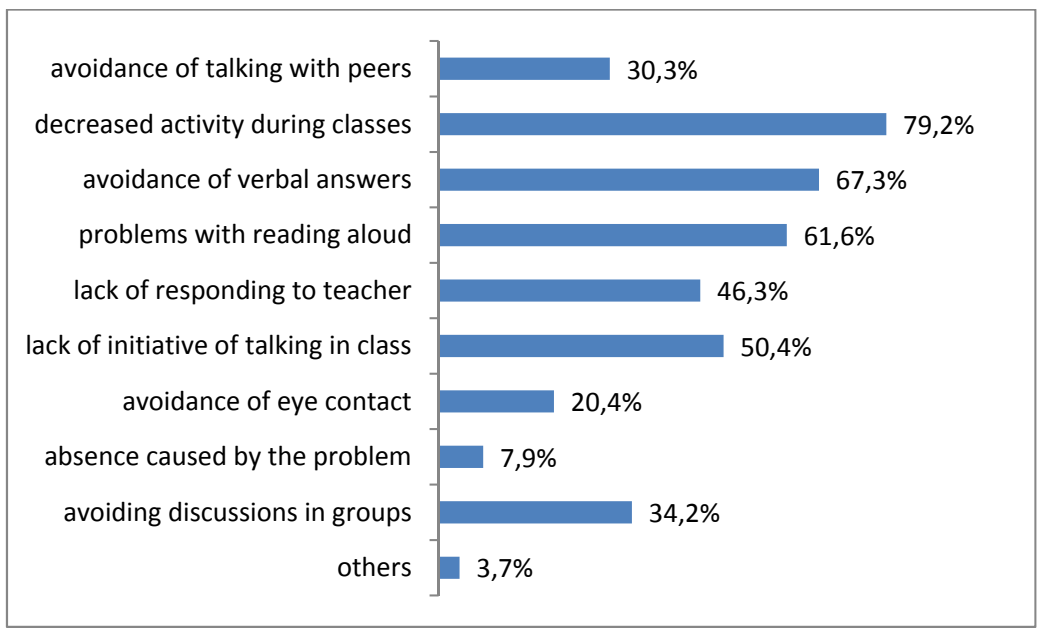

Figure 5. Typical behaviours of children with speech disorders indicated by teachers; $N=483$ Respondents could choose more than one answer.

Source: Own work

According to pedagogues, the most frequently indicated form of behaviour in relation to children with speech disorders was helping out in speaking. This type of behaviour allows for forecasting of long-term consequences for children who deal with such attitudes of peers in class. What is also unsettling is that teachers very often observe behaviours which can negatively influence the emotional functioning of a child with speech disorder among their pupils. A strong tendency was noticed suggesting that the younger the children are (at the preschool age), the more positive or neutral attitudes among peers took place, like empathy, cordiality or even the earlier mentioned helping out in speaking. According to the survey responses, kindergarten teachers very often filled out the questions with their own additional comments. In many cases, according to their opinion children do not pay attention to speech disorders as they themselves are not able to speak properly yet. One of the teachers wrote that "in my group, children do not react, sometimes even imitate their peers with speech disorders, there are very few negative reactions due to the age of the children". A few teachers of 1 st to 3 rd grade filled out their answers describing the following behaviours of peers: "help in translating the statements of a child with speech disorders", "patience among some children", "lack of reaction towards mistakes" and "protectiveness". The teachers of older students of primary schools (so-called specific subject teachers) and teachers of lower secondary schools much more often reported worrying behaviours within the classes. This included ridicule, spitefulness, mockery, lack of patience, and ruling out of the group or disregard. In the opinions of this group of pedagogues, 
the following descriptions came about: "bullying", "treating the child as a handicapped person", "leniency", "arrogance", "irritation during longer statements". The analysis of the teachers' responses indicates that mostly in the last years of primary school as well as lower secondary school, the situation of a child with communication problems is difficult and requires the support of the teacher as well as other specialists. On the other hand, according to the opinions of secondary schools teachers, there was an indication of more positive reactions in relation to students with logopedic problems. These results are in accordance with those which occurred among pedagogues taking care of younger children.

The next matter which was subjected for assessment by teachers concerned the typical behaviours of children featuring speech disorders (Figure 5).

It can clearly be seen that the surveyed teachers notice less activity among pupils with speech disorders during class. The majority of respondents also underlined the following worrying aspects of the behaviour of these children: avoidance of verbal answers, problems with reading aloud and lack of initiative of talking in class. The choice of these answers by a substantial part of the teachers is worrying. A slightly smaller group indicated behaviours such as: lack of responding to teachers, avoidance of talking to peers, avoiding discussions in group. Some teachers decided also to substantiate their answers by adding a description of other worrying reactions manifested by pupils with speech disorders: "the choice of roles and exercises which do not require speaking", "avoidance of spending time in a group, searching for contact with the teacher in privacy", "very quiet speech", "lack of confidence", "shyness". One of the teachers wrote: "this student is a loner". The problem of inadequate assessment of pupils' behaviour, e.g. those who stutter, was noted by English researchers, namely the perception of stuttering pupils as shy persons is often caused by a low level of knowledge among teachers regarding this condition. Pedagogues, who have the possibility to comprehend the essence of stuttering, along with its important component which is frequently occurring reactions of avoidance, are capable of a correct interpretation of behaviours of their pupils (Stewart, Turnbull, 2007). Similarly, as in the question about the reactions of peers in relation to pupils who featured speech disorders, teachers of kindergartens and first classes of primary schools frequently added comments to their answers. The general theme from these surveys is that in their opinion, during the early stages of education, children do not manifest negative reactions due to their speaking abilities. One of the teachers clearly denied the existence of any worrying behaviours among children. Another one commented on this particular question with the following words: "I don't observe such behaviours in my pupil with speech disorders." On the other hand, another teacher commented in the following way: "At the age from 7 to 9 years, apart from rare stuttering when a child refrains from speaking, no such behaviours described in the question occur." The most decisive in this matter were the opinions of kindergarten teachers, e.g.: "children do not manifest such behaviours", "on this stage of development 
(kindergarten) no problems with such behaviour can be found, the children like to be active during class and it can be said that they are not aware of their disorder.", "Little children are not aware of their condition, that is why they do not limit their verbal or linguistic activity". From the quoted statements it can be seen that teachers believe that being aware of one's own disorder as well as the emergence of related and unwanted reactions, like the exclusion from a group and lower activity at school, come out only in the case of somewhat older pupils - at the end of primary school education. According to teachers' observations, it is most likely that an assessment of the situation is also related with the intensification of negative peers' feelings towards the children with speech disorders.

Another question in the survey regarded the ways of providing support to a child with communication problems which are used by teachers (Figure 6).

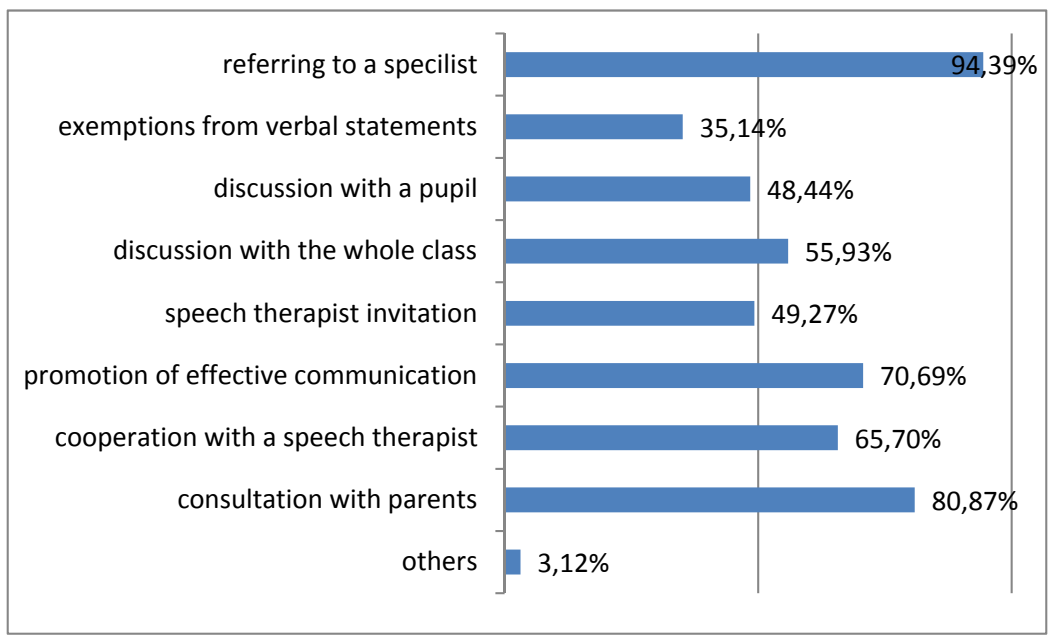

Figure 6 . The most preferred ways of providing support to a child with speech disorders; $\mathrm{N}=483$ Respondents could choose more than one answer.

Source: Own work

The results of this study consistently confirmed what was found in the previous research, namely that the most popular form of providing support by a teacher is referring a child/pupil to the specialist. More than $90 \%$ of respondents indicated this answer. It can be assumed that this is a form of moving the responsibility for a pupil onto other parts of the education system. However, the other results gathered in this area of the study seem to challenge this notion. The indication of other forms of help such as consultation with parents, promotion of effective communication in group/class and cooperation with speech therapists, all suggest that pedagogues to a big extent are focused on providing efficient support. Further ways of helping which were indicated by teachers included: "specific recommendation of 
exercises in order to aid a pupil", "suggesting to conduct specialist examinations in the case of a speech therapist not being employed in the school", "carrying out exercises during individual classes which are based on information derived from the academic literature", "positive support and paying attention to the progress made in carrying out exercises which all depend on pupil's engagement", "encouraging a child to making verbal statements", "individual work with a child", "adaptation of specific work methods according to the needs of each child", "promotion of pupil's advantages, talents and interests in order to pay attention to her/his strong sides without emphasizing child's shortcomings", "positive support, encouragement and adequate motivation", "choosing such forms of activities which do not require verbal statements to a big extent", "enhancing the faith in the possibilities of a child - each child requires individual support", "working with a child during correction classes". The number of additional answers indicated by teachers also gives evidence of substantial engagement in providing support to a child with communication problems.

Willingness to provide effective support to children also occurred indirectly in the answers on the last question which concerned the development of logopedic issues. Almost half of the respondents indicated that they are interested in gaining further knowledge in this field $(42.86 \%)$. It can be stated that it is a positive result, especially considering the fact that among the participants the most numerous group consisted of teachers with long work experience. Due to this fact it is a considerable possibility that this particular group of teachers has previously had the opportunity to take part in logopedic educational programs. Moreover, among the group of respondents who positively answered the question regarding the willingness for further development of their professional career skills, various topics which were interesting for the pedagogues were also indicated. The specific topics suggested by the teachers were the following: ways of providing support for a pupil with speech disorders; information regarding speech disorders; examples of exercises of the articulation organs based on games which could be implemented with a whole group in order to improve the functioning of those organs; exercises enhancing the speech apparatus; various kinds of logopedic games for the whole class/group; speech exercises with children who have speech disorders; physiological and psychological aspects of communication problems; helping a child with logopedic problems; adequate diagnosis during school years; early recognition of speech disorders; helping a child with mutism; advice for teachers of foreign languages on how to work with children with lisping; rhotacism and stuttering; stuttering and early learning on how to read; speech development of autistic children; delayed speech development, mutism and dyslalia; early logopedic intervention - cleft palate; how to help a stuttering child. Those very precise needs regarding further development of teachers' competences in the logopedic area seem to be a very positive issue according to which the determination of a considerable part of the pedagogues can be clearly noticed. 


\section{Discussion}

According to the results of this study it can be concluded that teachers usually know where the help should be found for a child with speech disorders. However, pedagogues often only pay attention to pronunciation problems. Moreover, teachers notice disturbing behaviours both among pupils with speech disorders as well as their peers. The results also showed that teachers perceive withdrawal behaviours and decreased activity among pupils with communication problems as well as increased negative and neutral reactions among children towards pupils with speech disorders. Furthermore, teachers indicate various ways of supporting the pupils by emphasising both the need for cooperation with a speech therapist as well as with the parents of the child. A major group of the respondents also showed an interest in further development of their competences in this area of knowledge.

The results of this study show that the pedagogues' environment notices the problems associated with the speech disorders and disturbing behaviours manifested by both the pupils with communication disorders and their peers. Based on the analysis of the data, the thesis can be drawn up that children's (pre-)school situation with communication problems is more and more often diagnosed by the teachers. It seems necessary to intensify the cooperation between speech therapists and pedagogues. This should lead to the acquisition of optimal standards of support providence and getting full involvement in the school/kindergarten life of these children. Supporting a child with communication disorders in the school environment seems to be one of the most important aims of the education system in which each of the pupils should have an opportunity for full realization. One of the bases of the effective cooperation between speech therapists and teachers should be sharing and disseminating of knowledge about the communication process and its disruptions, but also about the situation of a child with speechlanguage problems. Moreover, teaching pupils how to support peers with communication problems as well as promoting tolerance and optimal communication among children seems to be an important issue. One of the most important duties of teachers towards pupils with communication problems consists of being a role model - teachers should serve as a model in communication for pupils in their charge (Błachnio, 2001; Węsierska, 2007). This issue concerns both communication language spheres: verbal expressions (presenting a model conduct of the speaker), and speech recognition (showing ideal conduct of the listener) (Phyllis, 1975, p. 13). Also, a teacher has the possibility of supporting a child with communication problems through their specific attitude which is presented towards a pupil with a speech problem. An extremely important task of a teacher is providing support for a pupil with a speech disorder, especially in the building of self-confidence and high self-esteem. The teacher's reaction to the way the pupil 
expresses his/her opinions very often influences the pupil's mental state in the class. The teacher is responsible for shaping and correcting the attitudes of other pupils. Being an open-minded person as well as showing tolerance and acceptance plays a very important role in this process. Since 1947 the non-profit, American Stuttering Foundation provides support for stuttering people around the world. In the flyer directed to teachers the foundation recommends the following reactions:

- do not give the following advices: "slow down", "take a deep breath" or "relax yourself",

- do not add words for a child, do not speak out instead of a child; teach pupils the rules of telling one's opinions one by one and listening to each other (...),

- demand the same quality and quantity of work (...) from the stuttering person as you demand from the others,

- talk to the pupil who stutters in a calm manner, pause frequently,

- show that you are listening to what the stuttering person says but not how it is said,

- arrange a meeting in private with the stuttering pupil in order to discuss his/ her needs in class, respect those needs without giving a pupil special privileges,

- do not allow for the treatment of stuttering to be something which one should be ashamed of; do talk with pupils about stuttering openly, in the same way as you talk about other matters ${ }^{1}$.

Another essential issue refers to the early identification of speech disorders among the population of children and teenagers. The success of this process is determined by the active commitment of teachers with a simultaneous competent support of the speech therapists. Supporting therapeutic processes, cooperation as part of so-called therapeutic topics, close cooperation between specialists - teacher, speech therapist, psychologist or school pedagogues - and especially cooperation with the child's parents are the conditions which signify the effective logopedic assistance in the education system (McCartney, 2000; Płusajska-Otto, Węsierska, 2009; Płusajska-Otto, Węsierska, 2010, Rustin i in., 2002; Węsierska, 2007; Węsierska, 2009). The effective system of logopedic assistance is demonstrated by teachers who are actively engaged in various levels of logopedic influences, both on the disorder identification stage as well as during the therapy process (Haynes, Moran, Pindzola, 1990). It can be assumed that implementation of such a model requires close, coordinated actions of teachers and speech therapists with the partner contribution of parents as well as the subjects in question - pupils who experience communication problems. One of the most important rules of speech therapy, which determines its effectiveness, refers to the cooperation with the closest environment (Chęciek, 2007). Logopedic assistance -examined on all

\footnotetext{
${ }^{1}$ On the website of The Stuttering Foundation are accessible the Polish translations of materials promoting the teachers' awareness regarding the stuttering issues and the ways of providing support to the stuttering persons.
} 
its levels including prophylactic, diagnostic as well as therapeutic - in order to be fully effective "should be implemented with a cooperative partnership of the environments a child has contact with in order to be fully effective".

\section{References}

Alberts J.K., Nakayama T.K., Martin J.N. (2007). Human Communication in Society. Upper Saddle River: Pearson Education Inc.

Błachnio K. (2001). Vademecum logopedyczne. Poznań: Wydawnictwo Naukowe UAM.

Cantwell D.P., Baker L. (1985). Interrelationship of Communication, Learning, and Psychiatric Disorders in Children [In:] Simon Ch.S. [Ed.]. Communication Skills and Classroom Success. Assessment of Language-Learning Disabled Students. San Diego: College Hill Press, pp. 4361.

Chęciek M. (2007). Jąkanie. Diagnoza-terapia-program. Kraków: Oficyna Wydawnicza Impuls.

Cudak I., Matyja A. (2009). Akceptacja i tolerancja uczniów z problemami w komunikowaniu się w środowisku szkoły podstawowej. Forum Logopedyczne, 16, pp. 29-30.

Dramska D. (2001a). Proces instytucjonalizacji zawodu logopedy w Polsce. Katowice: Wydawnictwo Uniwersytet Śląskiego.

Dramska D. (2001b). Profesjonalna tożsamość logopedów w Polsce w świetle przeprowadzonych badań. Katowice: Wydawnictwo Uniwersytet Śląskiego.

Ebert K.A., Prelock PA. (1994). Teachers' Perceptions of Their Students with Communication Disorders. Language, Speech, and Hearing Services in Schools, vol. 25, pp. 211-214.

Grzybowska A., Łapińska I., Michalska R. (1991). Postawy nauczycieli wobec jąkania. Psychologia Wychowawcza, 2, pp. 139-149.

Haynes W.O., Moran M.J., Pindzola R.H. (1990). Communication Disorders. In the Classroom. Dubuque: Kendall Hunt Publishing Company.

Jastrzębowska G. (2003). Stan i perspektywy opieki logopedycznej w Polsce [In:] Gałkowski T., Jastrzębowska G. [Eds.]. Logopedia - pytania i odpowiedzi. Podręcznik akademicki, pp. 301314. Opole: Wydawnictwo Uniwersytetu Opolskiego.

Kania J.T. (2001). Szkice logopedyczne. Lublin: Polskie Towarzystwo Logopedyczne, Zarząd Główny.

Kasprzyk B., Stasiczek A., Węsierska K. (2005). Szkoła przyjazna uczniowi jąkającemu się - wyzwaniem dla logopedów. Śląsie Wiadomości Logopedyczne, 8, pp. 38-44.

Lass N.J., Ruscello D.M., Schmitt J.F., Pannbacker M.D., Orlando M.B., Dean K.A., Ruziska J.C., Harkins Bradshaw K. (1992). Teachers' Perceptions of Stutterers. Language, Speech, and Hearing Services in Schools, vol. 23, pp. 78-81.

Lees R.M. (2000). Stammering Children in Schools [in:] McCartney E. [ed.]: Speech/Language Therapists and Teachers Working Together. A Systems Approach to Collaboration, pp. 135149. Londyn: Whurr Publishers.

Matyja A., Cudak I,: Akceptacja i tolerancja uczniów z problemami w komunikowaniu się w środowisku szkoły podstawowej. Forum Logopedyczne, 2009, nr 16, s. 29-30.

McCartney E. (2000). Patterns of Collaboration [In:] McCartney E. [Ed.]: Speech/Language Therapists and Teachers Working Together. A Systems Approach to Collaboration, pp. 48-73. London: Whurr Publishers.

Michalak-Widera I. (2004). Zaburzenia dyslaliczne u dzieci realizujących edukację elementarną. Śląkie Wiadomości Logopedyczne, no 7, pp. 29-35.

Morreale S.P., Spitzberg B.H., Barge J.K.: Komunikacja między ludźmi. Motywacja, wiedza 
i umiejętności. Wydawnictwo Naukowe PWN, Warszawa 2007.

Phyllis P.P. (1975). Speech and Hearing Problems in the Classroom. Lincoln: Cliffs Notes Inc.

Płusajska-Otto A., Węsierska K.(2010). Rola nauczyciela w profilaktyce i terapii jąkania [in:] Baranowicz K., Sobczak A., Znajmiecka-Sikora M. [Eds.]: Rozwój i jego wspieranie w perspektywie nauk o człowieku - teoria i rozwiazania praktyczne, pp. 239-245. Łódź: Pracownia Pedagogiki Specjalnej WNoWUŁ.

Płusajska-Otto A., Węsierska K. (2009). Znaczenie wspótpracy logopedy i nauczyciela w terapii dziecka jąkającego się. "Forum Logopedyczne", no 17, pp. 29-34.

Rice M.L. (1993). "Don't Talk to Him, Hi's Weird." A Social Consequences Account of Language and Social Interactions [In:] Kaiser A.P., Gray D.B. [Eds.]. Enhancing Children's Communication. Research Foundations for Intervention, pp. 139-158.. Maryland: Paul H. Brookes Publishing Co.

Rice M.L., Sell M.A. (1990). Hadley P.A. Social interactions of speech- and language-impaired children. Journal of Speech and Hearing Research, vol. 34 (6), pp. 1299-1307.

Rustin L., Cook F., Botterill W., Hughes C., Kelman E. (2002). Stammering. A practical guide for teachers and other professionals. London: David Fulton Publishers Ltd.

Skorek E.M. (2000). Dzieci z zaburzeniami mowy wśród rówieśników w klasie szkolnej. Kraków: Oficyna Wydawnicza Impuls.

Sobol E., [Ed.], (1999). Mały słownik języka polskiego. Warszawa: Wydawnictwo Naukowe PWN.

Stecko E. (2001). Zaburzenia mowy u dzieci-wczesne rozpoznawanie i postepowanie logopedyczne. Warszawa: Wydawnictwo Uniwersytetu Warszawskiego.

Stewart J. [Ed.], (2007). Mosty zamiast murów. Podręcznik komunikacji interpersonalnej. Warszawa: Wydawnictwo Naukowe PWN.

Stewart T., Turnbull J. (2007). Working with Dysfluent Children. Practical Approaches to Assessment and Therapy. Brackley: Speechmark Publishing Ltd.

Tarkowski Z. (2005). Wizerunek zawodowy i społeczny logopedy [In:] Młynarska M., Smereka T. [Eds.]: Logopedia. Teoria i praktyka, pp. 395-405. Wrocław: Agencja Wydawnicza a linea.

Trzaskalik J. (1998). O konieczności badań nad wpływem chorób układu oddechowego na wady u dzieci w województwie katowickim [In:] Nowakowska-Kempna I. [Ed.]: Effata-Otwarcie. Logopedia jako nauka interdyscyplinarna i stosowana. Katowice: Uniwersytet Śląski, pp. 243249.

Węsierska K. (2009). Profilaktyczno-terapeutyczne działania logopedów w środowisku życia dzieci $w$ wieku przedszkolnym. Unpublished doctoral dissertation, prepared under the direction of Professor E. Syrek at the University of Silesia. Katowice.

Węsierska K. (2007). Profilaktyka logopedyczna w edukacji przedszkolnej - rola nauczyciela. Wychowanie na co Dzień, 6 (165), pp. 8-11.

Wintgens A. (2002). Links Between Emotional/Behavioral Problems and Communication Difficulties [In:] Kersner M., Wright J.A. [Eds.]. How to Manage Communication Problems in Young Children, pp. 63-74.. London: David Fulton Publishers.

Van Riper Ch., Erickson R.L.: Speech Correction. An Introduction to Speech Pathology and Audiology. Allyn and Bacon, Needham Heights. 